\title{
PEMBERIAN EKSTRAK DAUN Tagetes erecta L DENGAN DOSIS BERBEDA SEBAGAI ANTI JAMUR Saprolegnia sp. PADA PENETASAN TELUR IKAN TAWES (Barbonymus gonionotus)
}

\section{Tagetes erecta L LEAF EXTRACT WITH DIFFERENT DOSES AS Saprolegnia sp. ANTIFUNGALS IN Barbonymus gonionotus EGG HATCHING}

\author{
Sufal Diansyah ${ }^{1}$, T. Amarullah ${ }^{2}$, Shela Rahmita $^{3}$, Sukardi $^{3}$ \\ ${ }^{1}$ Program Studi Akuakultur, Fakultas Perikanan dan Ilmu Kelautan, Universitas Teuku Umar, Aceh Barat \\ ${ }^{2}$ Program Studi Sumberdaya Akuatik, Fakultas Perikanan dan Ilmu Kelautan, Universitas Teuku Umar \\ ${ }^{3}$ Program Studi Perikanan, Fakultas Perikanan dan Ilmu Kelautan, Universitas Teuku Umar, Aceh Barat \\ Korespondensi: sufaldiansyah@utu.ac.id
}

\begin{abstract}
ABSTRAK
Penelitian ini bertujuan untuk mengetahui konsentrasi yang tepat dan keefektifan ekstrak Tagetes erecta L dalam pengendalian infeksi jamur Saprolegnia sp. Penelitian ini dilaksanakan selama tiga bulan. Ekstraksi dilaksanakan di Laboratorium Teknologi Hasil Pertanian (THP) Fakultas Pertanian Universitas Syiah Kuala dan Uji Fitokimia dilaksanakan di Laboratorium Fakultas Matematika dan Ilmu Pengetahuan Alam (MIPA), uji In- Vivo dilaksanakan di Balai Benih Ikan Krueng Batee Kabupaten Aceh Barat Daya. Penelitian ini menggunakan Rancangan Acak Lengkap (RAL), masing- masing dengan tiga taraf perlakuan dan tiga kali ulangan. Perlakuan yang digunakan adalah perendaman ekstrak Tagetes erecta $\mathrm{L}$. dengan konsentrasi berbeda, yakni konsentrasi 45 ppm (P1), konsentrasi 50 ppm (P2), konsentrasi 55 ppm (P3). Parameter yang diamati meliputi Uji Fitokimia daun Tagetes erecta L., daya tetas telur, dan parameter kualitas air. Hasil uji fitokimia menunjukkan bahwa ekstrak daun tahi ayam (Tagetes erecta $\mathrm{L}$ ) mengandung beberapa senyawa bioaktif yang meliputi; alkaloid, steroid, tanin, dan fenolik. Hasil penelitian menunjukkan bahwa daya tetas telur ikan tawes yang diberikan ektrak daun Tagetes erecta L menunjukkan tingkat penetasan yang berbeda-beda yaitu 95\% (P1), 96,67\% (P2), dan 97,66 (P3). Hal ini menunjukkan bahwa semua perlakuan memiliki daya tetas diatas 90 persen, yang mengindikasikan bahwa dosis yang diberikan berada pada kisaran optimal.
\end{abstract}

Kata kunci: Barbonymus gonionotus, daya tetas telur, infeksi jamur, senyawa bioaktif.

\begin{abstract}
This research was carried out for three months. The extraction was carried out at the Laboratory of Agricultural Product Technology Faculty of Agriculture, Syiah Kuala University and the Phytochemical Test was carried out in the Laboratory of the Faculty of Mathematics and Natural Sciences (MIPA), the In-Vivo test was carried out in Hatchery Krueng Batee, Aceh Barat Daya District. This study used a Completely Randomized Design, each with three treatment levels and three replications. The treatment used was immersion of Tagetes erecta $\mathrm{L}$ extract with different concentrations, ie concentration of $45 \mathrm{ppm}(\mathrm{P} 1)$, concentration of $50 \mathrm{ppm}(\mathrm{P} 2)$, concentration of 55 ppm (P3). Parameters observed included phytochemical test of Tagetes erecta L leaf, hatchability of eggs, and water quality parameters. Phytochemical test results showed that Tagetes erecta L leaf extract contains several bioactive compounds which include; alkaloids, steroids, tannins, and phenolics. The results showed that the hatchability of the eggs given by Tagetes erecta L leaf extract showed different hatching rates of 95\% (P1), 96.67\% (P2), and 97.66 (P3). This shows that

\footnotetext{
${ }^{1}$ Fakultas Perikanan dan Ilmu Kelautan, Universitas Teuku Umar Korespondensi: Jurusan Akuakultur, Fakultas Perikanan dan Ilmu Kelautan, Universitas Teuku Umar, Kampus UTU Meulaboh, Alue Peunyareng 23615, Telp: +62 8116804788, email: sufaldiansyah@utu.ac.id
} 
all treatments have hatchability above 90 percent, which indicates that the dose given is in the optimal range.

Keywords: Barbonymus gonionotus, hatchability of eggs, fungal infections, bioactive compounds.

\section{PENDAHULUAN}

Ikan Tawes (Barbonymus gonionotus) merupakan salah satu jenis ikan air tawar yang mempunyai nilai ekonomis di daerah Aceh. Ikan jenis ini sudah dibudidayakan oleh masyarakat Aceh, hal tersebut dikarenakan ikan Tawes digemari oleh masyarakat. Sebagai bahan pangan, ikan Tawes memiliki tekstur daging yang kenyal dan sedikit lemak menyerupai daging ikan mas, di samping itu harga ikan Tawes dapat terjangkau oleh masyarakat.

Salah satu faktor penentu dalam bisnis budidaya ikan adalah ketersediaan benih ikan yang berkualitas. Pembenihan ikan tawes sering menghadapi kendala, diantaranya adalah serangan jamur pada telur ikan saat fase penetasan. Jenis jamur yang sering menyerang telur ikan tawes adalah Saprolegnia sp. Ciri-ciri telur ikan yang terserang jamur Saprolegnia sp. dipenuhi benang-benang putih seperti kapas yang tumbuh pada telur ikan (Widya et al., 2014)

Penanggulangan infeksi jamur pada saat penetasan telur umumnya menggunakan antibiotik dan senyawa sintetik lainnya. Penggunaan antibiotik saat ini sudah dilarang karena dapat menimbulkan efek resisten pada jamur dan bakteri pathogen yang terdapat di dalam media penetasan serta mengakibatkan pencemaran lingkungan. Solusi untuk mengatasi masalah tersebut, maka perlu adanya bahan alternatif yang lebih aman dan dapat mengendalikan penyakit akibat jamur Saprolegnia $s p$. Salah satu bahan yang dapat digunakan adalah penggunaan tanaman yang bersifat anti jamur. Penggunaan tanaman sebagai obat memiliki beberapa keuntungan yaitu bahan alami pengganti antibiotik, ramah terhadap lingkungan, tidak menyebabkan resistensi pada ikan, mudah diperoleh dan harganya ekonomis (Permatasari, et.al., 2013).

Bahan-bahan alami yang telah banyak digunakan sebagai anti jamur pada telur ikan antara lain daun kelor, daun pepaya (Septiani, et.al., 2016), minyak astiri (2007) dan lain sebagainya. Beruntung, Indonesia sebagai negara agraris yang memiliki iklim tropis memiliki kekayaan alam yang luar biasa, beragam jenis tanaman terdapat di negara ini sehingga masih banyak sekali jenis tanaman berkhasiat obat lainnya yang belum tergali potensinya secara maksimal. Salah satunya adalah tanaman yang sudah sangat akrab dengan kehidupan masyarakat Aceh, daun bunga tahi ayam (Tagetes erecta $L$ ).

Tanaman ini mudah didapat dan dikenal mengandung khasiat obat. Tagetes erecta $L$ biasa digunakan untuk mengobati sakit perut pada manusia, dan penyakit lainnya. Namun, penggunaan tanaman Tagetes erecta $L$ sebagai bahan pengendalian jamur saprolegnia $s p$ pada telur ikan belum dilakukan. Menurut Chivde (2011) Daun bunga tahi ayam memiliki kandungan kimia sebagai anti jamur yaitu beberapa Flavonoid seperti Kuersetagenin, Tagettin, Kaemferol dan Kaemferitin.

\section{METODE PENELITIAN}

\section{Rancangan percobaan}

Penelitian ini menggunakan rancangan acak lengkap, masing- masing dengan tiga taraf perlakuan pemberian ekstrak daun Tagetes erecta $\mathrm{L}$ dengan dosis berbeda dan masing-masing perlakuan diulang sebanyak tiga kali. Dosis yang digunakan adalah $45 \mathrm{ppm}$ (P1), $50 \mathrm{ppm}$ (P2), dan 55 ppm (P3). 


\section{Prosedur penelitian}

\section{Pembuatan ekstrak daun Tagetes erecta $\mathrm{L}$}

Daun Tagetes erecta $L$ yang digunakan dicuci bersih dan dikering anginkan selama tiga hari. Setelah kering Daun Tagetes erecta $L$ dihaluskan sampai menjadi serbuk. Serbuk daun Tagetes erecta $L$ ditimbang sebanyak 500 gram dan ditambahkan sedikit demi sedikit pelarut methanol p.a sebanyak 4 liter hingga seluruhnya terendam sambil diaduk, dengan lama perendaman 48 jam. Larutan hasil ekstraksi disaring dengan kertas Whatman No.1 dan hasilnya dimasukkan ke dalam botol tertutup untuk selanjutnya dievaporasi. Ekstrak daun yang diperoleh dipekatkan dengan menggunakan rotary evaporator pada suhu $58-60^{\circ} \mathrm{C}$ hingga diperoleh larutan yang kental. Ekstrak daun Tagetes erecta $L$ disimpan dalam freezer sampai digunakan.

\section{Uji Fitokimia Tagetes erecta $\mathbf{L}$}

Uji fitokimia Tagetes erecta $L$ merupakan uji yang dilakukan untuk mengetahui senyawa-senyawa kimia yang terdapat didalamnya. Tahapan pengujian saponin, flavonoid, alkaloid dan fenolik dilakukan berdasarkan metode Harborne (1998) dan pengujian glikosida berdasarkan metode Medika Indonesia tahun 1995.

Simplisia sebanyak 10 gram dimasukan kedalam labu erlemeyer yang berisi pelarut methanol $100 \mathrm{ml}$ kemudian diaduk dan direndam selama 24 jam.

\section{a. Pengujian golongan saponin}

Setelah 24 jam ampas dari proses maserasi diambil dengan spatula sebanyak 0,5 gram dan dimasukkan kedalam tabung reaksi dan ditambahkan $10 \mathrm{ml}$ aquades. Tabung reaksi dikocok hingga muncul buih. Ekstrak diberi 1 tetes $\mathrm{HCl}$, bila buih terbentuk \pm 10 menit maka positif terdapat senyawa saponin.

\section{b. Pengujian golongan flavonoid}

Ekstrak sampel diambil $1 \mathrm{ml}$ dimasukkan kedalam tabung reaksi kemudian ditambah $\mathrm{FeCl}_{3}$ 1\% jika terjadi perubahan warna menjadi merah jingga maka positif terdapat senyawa flavonoid.

c. Pengujian golongan alkaloid

Ekstrak sampel diambil $4 \mathrm{ml}$ dimasukkan masing-masing $1 \mathrm{ml}$ kedalam 4 tabung reaksi. Tabung pertama ditambah 2 tetes pereaksi Bouchardat, apabila terbentuk endapan berwarna cokelat sampai hitam maka sample positif alkaloid. Tabung kedua ditambah 2 tetes pereaksi Dragendroff, apabila terbentuk endapan berwarna merah/jingga maka sample posistif alkaloid. Tabung ketiga ditambah 2 tetes pereaksi Wagner, apabila terbentuk endapan berwarna cokelat maka sample positif alkaloid.

\section{d. Pengujian golongan fenolik}

Ekstrak sampel diambil $1 \mathrm{ml}$ dimasukan kedalam tabung reaksi kemudian ditambah $\mathrm{FeCl}_{3}$ 1\% jika terjadi perubahan warna menjadi hitam maka positif terdapat senyawa fenolik.

\section{Uji In Vivo}

1. Persiapan Wadah

Wadah pemeliharaan digunakan adalah viber glass volume $1000 \mathrm{ml}$ sebanyak sembilan unit, Semua wadah penelitian sebelum digunakan terlebih dahulu di sucihamakan dengan cara dicuci dan dijemur.

\section{Pembuatan Larutan Uji}

Bahan ekstrak Tagetes erecta $L$ diukur dengan kebutuhan setiap perlakuan yaitu : 45 ppm, $50 \mathrm{ppm}, 55 \mathrm{ppm}$. Setelah larutan ekstrak Tagetes erecta $L$ didapat melalui dosis, kemudian digunakan terhadap perendaman telur untuk mengetahui daya tetas telur dari serangan jamur Saprolegnia sp. 


\section{Penanganan Telur}

Sampel yang digunakan dalam penelitian ini adalah telur ikan Tawes (Puntius javanicus) yang diperoleh dari hasil pemijahan semi buatan di BBI Krueng Batee Kecamatan Kuala Batee Kabupaten Aceh Barat Daya. Telur sehat yang telah terbuahi diambil sebanyak 100 butir untuk setiap wadah dan 25 butir telur yang telah terinfeksi jamur. Sebanyak 25 butir telur yang telah terinfeksi jamur dimasukkan ke dalam masing-masing wadah (toples) yang berisi 100 butir telur sehat dan dipasang aerator. Telur sehat dibiarkan terendam selama 1 jam sampai terinfeksi jamur. Telur sehat yang telah terinfeksi jamur langsung dipindahkan ke dalam masing-masing wadah yang telah diberi larutan ekstrak Tagetes erecta sesuai konsentrasi yang ditentukan untuk setiap perlakuan. Perendaman dalam larutan ekstrak daun Tagetes erecta dilakukan sampai telur menetas.

\section{Parameter Uji}

Parameter yang diamati pada penelitian ini adalah daya tetas telur, kondisi perkembangan telur, parameter kualitas air.

\section{Daya tetas telur}

Setelah penetasan terjadi maka dilakukan pengamatan untuk mengetahui daya tetas telur atau hatching rate. Upaya ini bertujuan untuk mengetahui jumlah telur yang menetas dari jumlah telur yang dihasilkan. Pada saat telur sudah menetas semua, larva dihitung kemudian dilakukan perhitungan mencari hatching rate dengan menggunakan rumus menurut Effendie (1997).

$$
H R=\frac{\text { Junlah telur yang menetas }}{\text { Jumlah total telur }} \times 100 \%
$$

2. Kondisi perkembangan telur

Kondisi perkembangan telur ikan Tawes diamati mulai dari awal pembuahan atau setelah terbuahi oleh sperma hingga telur menetas. Pengamatan dilakukan menggunakan alat bantu mikroskop digital selang waktu per satu jam, kemudian perkembangan telur difoto sebagai dokumentasi. Telur yang telah diamati dikembalikan lagi ke dalam wadah.

\section{Parameter kualitas air}

Pengukuran kualitas air dilakukan dari awal sampai akhir proses penetasan telur ikan tawes, yang meliputi suhu, $\mathrm{pH}$, dan kandungan oksigen terlarut (DO).

\section{Analisis Data}

Data hasil pengamatan dihitung untuk mendapatkan parameter biologi yaitu nilai daya tetas telur dan daya hambat. Data hasil perhitungan ditabulasi dan dianalisis menggunakan program Microsoft Excel 2013 dan SPSS 16.0. Data parameter biologi dianalisis dengan analisis ragam (Anova) pada selang kepercayaan $95 \%$. Analisis ini digunakan untuk menentukan apakah perlakuan berpengaruh nyata terhadap parameter biologi. Apabila berpengaruh nyata dilakukan uji lanjut Tukey pada selang kepercayaan $95 \%$ untuk menentukan perbedaan antar perlakuan. Kondisi perkembangan telur dan parameter kualitas air dianalisis secara deskriptif dengan penyajian gambar atau tabel.

\section{HASIL DAN PEMBAHASAN}

\section{Hasil}

Senyawa Kimia Daun Tanaman Tahi Ayam (Tagetes erecta $\mathrm{L}$ )

Hasil uji fitokimia menunjukkan bahwa ekstrak daun tahi ayam (Tagetes erecta $\mathrm{L}$ ) mengandung beberapa senyawa bioaktif yang meliputi; alkaloid, steroid, tanin, dan fenolik (Tabel 1). Masing-masing senyawa tersebut memiliki manfaat dan fungsi yang berbeda.

\section{Daya Tetas Telur}

Hasil penelitian daya tetas telur ikan tawes yang diberikan ektrak daun Tagetes erecta $\mathrm{L}$ menunjukkan tingkat penetasan yang 
berbeda-beda yaitu (Gambar 1). Hal ini menunjukkan bahwa semua perlakuan memiliki daya tetas diatas 90 persen, yng mengindikasikan bahwa dosis yang diberikan berada pada kisaran optimal.

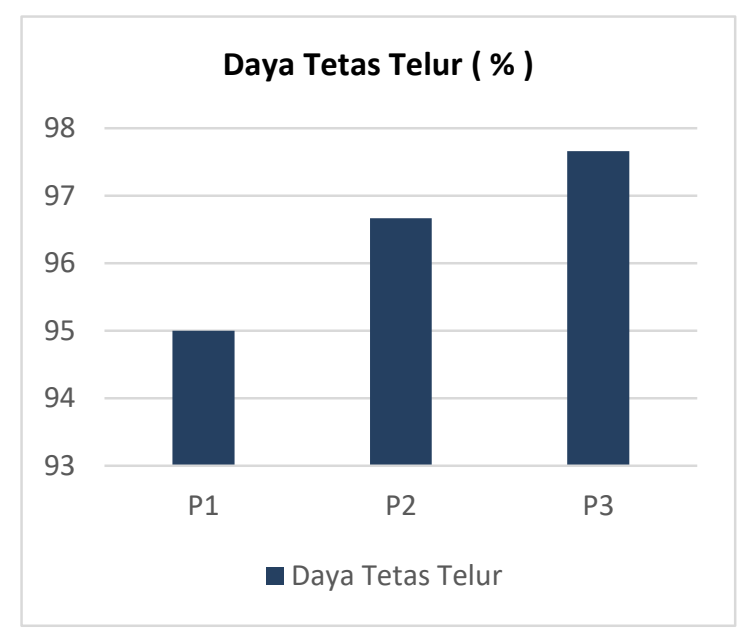

Gambar 1. Daya tetas telur ikan tawes yang diberikan ekstrak Tagetes erecta L dengan dosis yang berbeda

Kondisi perkembangan Telur

Proses pembentukan embriogenesis ikan tawes berlangsung selama 260 menit setelah pemijahan, kemudian berkembang menjadi beberapa fase. Proses perkembangan telur ikan (embriogenesis) terdiri dari 6 fase yaitu fase cleavage, morula, blastula, gastrula, organogenesis dan fase larva.

\section{Kualitas Air}

Parameter kualitas air yang diukur pada penelitian ini meliputi, suhu, $\mathrm{pH}$ dan DO. Data kualitas air selama penelitian berada pada kisaran optimal untuk proses penetasan ikan tawes.
Tabel 1. Hasil uji fitokimia ektrak daun tahi ayam (Tagetes erecta L).

\begin{tabular}{cccc}
\hline $\begin{array}{c}\text { Kandunga } \\
\text { n Kimia }\end{array}$ & Reagen & $\begin{array}{c}\text { Sampel Segar } \\
\text { Tagetes } \\
\text { erecta } \mathrm{L}\end{array}$ & Hasil \\
\hline Alkaloid & Mayer & + & Endapan \\
\hline & Wagner & + & $\begin{array}{c}\text { Endapan } \\
\text { Merah }\end{array}$ \\
\hline & Dragendorff & + & $\begin{array}{c}\text { Endapan } \\
\text { Putih }\end{array}$ \\
\hline Steroid & Uji & + & $\begin{array}{c}\text { Warna } \\
\text { Hijau }\end{array}$ \\
\hline Terpenoid & $\begin{array}{c}\text { Uji } \\
\text { Liebermann }\end{array}$ & - & $\begin{array}{c}\text { Warna } \\
\text { Merah }\end{array}$ \\
\hline Saponin & Pengocokan & - & Berbusa \\
\hline Flavonoid & $\begin{array}{c}0,5 \mathrm{~g} \mathrm{Mg} \\
\text { dan HCl }\end{array}$ & + & $\begin{array}{c}\text { Warna } \\
\text { Merah }\end{array}$ \\
\hline Tanin & MgCl3 & + & $\begin{array}{c}\text { Coklat } \\
\text { Kehitaman }\end{array}$ \\
\hline Fenolik & MgCl3 & + & $\begin{array}{c}\text { Coklat } \\
\text { Kehitaman }\end{array}$ \\
\hline & & &
\end{tabular}

\section{Pembahasan}

Telur ikan merupakan senyawa organik bening yang dihasilkan oleh induk betina berupa butiran-butiran kecil berbentuk bulat dan membutuhkan proses pembuahan (fertilisasi). Pada Telur ikan diketahui relatif sensitif terhadap serangan organisme biotik yang terdapat di dalam air salah satunya serangan jamur. Secara alamiah, jamur ini akan menyerang telur-telur yang tidak terbuahi. Meskipun demikian, tidak menutup kemungkinan jamur ini akan menyerang telur- telur yang terbuahi. Hal ini sesuai dengan pernyataan Bowo (2014) yaitu secara umum, hampir semua telur jenis ikan rentan terhadap serangan jamur. Spora jamur Saprolegnia $s p$. Akan menyerang kulit telur ikan dengan adhesi dan penetrasi. Pada telur ikan tawes yang terserang jamur akan memperlihatkan tanda-tanda di sekeliling telur terdapat benang-benang halus seperti kapas. Kabata (1985) dalam Bowo (2014) menyatakan bahwa pada awalnya jamur akan menyerang telur ikan tidak 
berbahaya, tapi bila serangannya tidak dihentikan maka jamur akan menyebar pada telur yang lain dan telur tersebut akan mati. dan perkembangan jamur Saprolegnia $S p$ terjadi karena adanya lapisan minyak yang terdapat pada telur dan akan menyebar pada telur yang hidup. Akibatnya telur akan terinfeksi jamur yang akhirnya akan mengalami kematian karena respisari telur terganggu oleh miselium jamur (Tang, 1999 dalam Almufrodi, 2012).

Telur yang terinfeksi Saprolegnia $s p$. Tidak dapat berkembang dengan baik menjadi embrio karena terjadinya penyerapan glukoprotein telur oleh hifa jamur Saprolegnia $s p$. Hal ini sesuai deangan pendapat Espeland dan Hansen (2004) yang menyatakan bahwa kandungan kimia pada telur yang terbuahi menarik jamur sehingga jamur bergerak secara kemotoksis positif. Mengakibatkan jamur semakin mendekat dan akhirnya menempel pada telur. Menurut Woynarovich dan Horvath (1980) dalam Lingga (2012), saat jamur semakin mendekat dan kemudian menempel pada telur, kandungan gluprotein akan dihisap melalui benang-benang halus pada jamur yang disebut hifa, sehingga kulit telur akan melemah dan kekakuan telur menghilang, Akibatnya telur akan mengkerut dan akhirnya mati.

Daya tetas telur ikan tawes yang diberi perlakuan ekstrak Tagetes erecta $L$ adalah berkisar 95-97,66\%. Ekstrak daun bunga tahi ayam memberikan perlindungan yang efektif terhadap infeksi jamur Saprolegnia $s p$ yang terdapat di dalam wadah uji coba. Hasil penelitian ini menunjukkan perlakuan ekstrak Tagetes erecta $L$ atau daun bunga tahi ayam. hasilnya lebih baik dari pada kontrol, sehingga ekstrak daun tahi ayam bisa digunakan untuk meningkatkan daya tetas telur ikan tawes. Hasil ini menunjukkan perlakuan Tagetes erecta $L$ efektif membasmi jamur Saprolegnia $S p$ pada penetasan telur ikan tawes.

Parameter kualitas air selama penelitian berkisar antara 25,8 $29,1{ }^{\circ} \mathrm{C}$ untuk suhu dan DO air berkisar antara
4,1-4,8 mg/L, nilai tersebut dinilai masih sesuai dengan kisaran nilai kualitas air yang baik untuk penetasan telur ikan tawes. Air yang digunakan adalah air yang mengalir langsung dari daerah pegunungan yang ada di daerah Aceh Barat Daya sehingga kondisi ini sangat baik dalam hal budidaya ikan terutama dalam hal penanganan telur ikan.

\section{KESIMPULAN}

Pemberian ekstrak Tagetes erecta L sangat efektif dalam pengendalian infeksi jamur Saprolegnia sp. pada proses penetasan telur ikan tawes (Puntius javanicus).

\section{UCAPAN TERIMA KASIH}

Ucapan terima kasih kepada Kemenristekdikti yang telah mendanai penelitian ini. Kegiatan penelitian ini berjalan dengan baik dan lancar atas peran LPPM UTU.

\section{DAFTAR PUSTAKA}

Afrensi, 2007. Pengaruh Minyak Astiri Kemangi (Ocimum basilicumforma citratum Back) Terhadap Infestasi Larva Lalat Hijau (Chrysomya megacephala) Pada Ikan Mas (Cyprinus arpio). [Skripsi]. Diakses di http://journal.ipb.ac.id/index.php /jai/article/view/4077/2804

BPTO, 2008. Buku Pintar Tanaman Obat: 431 jenis tanaman penggempur aneka penyakit. Penerbit AgroMedia. Jakarta

Ciptanto, S., 2010. Top 10 Ikan Air Tawar. Lily Publisher. Yogyakarta

Chivde.B.2011. In-Vitro Antioxydant Activity Studies on the Flowers of Tagetes erecta $L$ (Compositae)

Karwani, G dan Siddhraj, S.S. 2015. Tagetes erecta plant: Review with significant pharmacological activities. Bhupal Nobles' College of Pharmacy, Udaipur, Rajasthan, 313 001, India. World 
Journal of Pharmaceutical Sciences. ISSN : 2321-3310

Kottelat, 1993. Freshwater fishes of western Indonesia and Sulawesi. Periplus edition, hongkong. P. 66

Meyer, F.P. 1991. Aquaculture diasese and health management. J. amin. 42014208

Noga, E.J. 1996. Fish Disease. Diagnosis and Treatment. Department of Companion Animal \& Special Species Medicine. North Caroline State University. hlm. 2325

Permatasari, G. A. A, I. N. K Besung . H Mahatmi, 2013 Daya Hambat Perasan Daun Sirsak Terhadap Peetumbuhan Bakteri Escherichia coli. Jurnal Indonesia Medicus Veterinus. 2013 2(2) : $162-169$

Rahmaningsih, S. 2011. Pengaruh Ekstrak Sidawayah dengan Konsentrasi yang Berbeda untuk Mengatasi Infeksi Bakteri Aeromonas hydrophyla pada Ikan Nila (Oreochromis niloticus). Jurnal Ilmu Perikanan dan Sumberdaya Perairan

Santoso, B. dan T.S. Wikatma. 2001. Petunjuk Praktis Budidaya Tawes. Yogyakarta: Penerbit Kanisius

Susanto, H. 2000.Budidaya Ikan Koi. Penebar Swadaya. Jakarta

Syamsuhidayat. 1991. Inventarisasi Tanaman Obat Indonesia, edisi kedua, Departemen Kesehatan RI, Jakarta.

Vandenberg.G.2008. Evaluation of Antifungal Activity of $\mathrm{CHCx}$ Formulation Against Saprolegnia paracitica Research Report.

Widya, D. R., D. Suryanto, Desrita. 2014. Aktivitas antimikroba biji teratai (Nymphaea pubescens L.) terhadap bakteri Aeromonas hydrophilla, Streptococus agalactiae, dan jamur Saprolegnia sp. Jurnal Mikrobiologi. 2(1):7-17
Witjaksono. 2009. Kinerja Produksi Pendederan Lele Sangkuriang Clarias sp. Melalui Penerapan Teknologi Ketinggian Media Air $15 \mathrm{Cm}, 20 \mathrm{Cm}$, $25 \mathrm{Cm}$, dan $30 \mathrm{Cm}$. Institut Pertanian Bogor, Bogor. 